\title{
ВАРВАРИ ЧИ РОМЕЇ? ДО ПИТАННЯ ПРО РОЛЬ ВАРВАРСЬКОГО КОМПОНЕНТА В ЕТНІЧНОМУ СКЛАДІ НАСЕЛЕННЯ РАННЬОСЕРЕДНЬОВІЧНОГО ХЕРСОНЕСА-ХЕРСОНА
}

\author{
М. В. Пархоменко
}

\begin{abstract}
Пархоменко М. В. Варвари чи ромеї? До питання про роль варварського компонента в етнічному складі населення ранньосередньовічного Херсонеса-Херсона. У статті розглядається роль варварського компонента у формуванні міського етнічного субстрату в IV-X ст. Час Великого переселення народів додав нові компоненти до етнічної мозаїки Херсонеса-Херсона. Грецький етнічний субстрат, швидше за все, втрачає своє цілковите домінування до Х ст. Жителі міста, об'єднані новою вірою, загальною ромейською культурою і мовою, змогли згуртуватися в новий багатонаціональний моноліт, зрозумілий для себе, але дивний і незвичний для столичних інтелектуалів.
\end{abstract}

Ключові слова: варвари; ромеї; етнічний склад; ранньосередньовічний Херсонес-Херсон.

Пархоменко М. В. Варвари или ромеи? К вопросу о роли варварского компонента в этническом составе населения раннесредневекового Херсонеса-Херсона. В статье рассматривается роль варварского компонента в формировании городского этнического субстрата в IV-X вв. Время Великого переселения народов добавило новые компоненты в этническую мозаику Херсонеса-Херсона. Греческий этнический субстрат, скорее всего, теряет абсолютное доминирование к X в. Жители города, объединенные новой верой, общей ромейской культурой и языком, смогли сплотиться в новый многоэтничный монолит, понятный для себя, но все еще «странный и необычный» для столичных интеллектуалов.

Ключевые слова: варвары; ромеи; этнический состав; раннесредневековый Херсонес-Херсон.

Parkhomenko M. V. Barbarios or Romanioi? On the Role of Barbaric Component in the Ethnic Structure of the Population of Early Medieval Chersonesus-Cherson. The article examines the role of the barbaric component in the formation of urban ethnic substrate in the 4th-10th centuries. The Time of Great Migration added new components to the ethnic mosaic of Chersonesus-Cherson. The residents of the city, united by a new faith, common Roman culture and language, were able to rally to a new multi-ethnic monolith, an understandable for themselves but still strange and unusual for metropolitan intellectuals.

Keywords: Barbarians; Romaioi; ethnic structure; Early Medieval Chersonesus-Cherson.

Проблема етнічного складу Херсонеса-Херсона доби раннього середньовіччя складна, дискусійна і специфічна, вимагає спеціального розгляду. Звертаючись до неї, С. В. Ушаков зазначає, що в археології Північного Причорномор'я на початку існувала низка невирішених питань, пов'язаних з проблемою етнорелігійної ідентифікації малих груп населення міст ${ }^{1}$. А. І. Романчук також зауважує, що етнічна історія Таврики пізньоантичного та ранньосередньовічного часу належить до переліку найскладніших тем. Як і у багатьох інших випадках, причиною, що не дозволяє скласти цілісну картину, є стан джерел: їхня фрагментарність і нечисельність, а також суперечливість повідомлень стародавніх авторів щодо племінного світу Північного Причорномор'я².

Разом 3 тим, зі зрозумілих причин, у вітчизняній науці ця тематика тривалий час залишалася non grata - якщо вона і розглядалася, то вузько філологічно (або виключно в ракурсі соціально-класових побудов) i, головним чином, на матеріалах епіграфіки. Відповідно, в сфері «німої» археологічної повсякденності (стародавні споруди, культове і побутове начиння, продукція художнього ремесла) тільки зараз відбувається пошук і виявлення «індикаторів» присутності різних етнічних компонентів, що особливо важливо для тих періодів та регіонів, де свідчення античних та середньовічних авторів і епіграфіки відсутні або фрагментарні ${ }^{3}$.

Питання про варварський компонент у етнічному складі ранньовізантійського Херсонеса-Херсона неодноразово піднімалося дослідниками ${ }^{4}$. Але єдиним випадком, коли цю проблему була розглянуто спеціально, є робота А. І. Айбабіна про етнічну історію Криму5.

(C) Пархоменко, М. В., 2017 
Автор узагальнив уявлення попередників і відтворив традиційну схему етнічних процесів, 3 якою донині погоджується більшість науковців: Херсонес за пізньоантичної доби був заселений панівним грецьким населенням, отримав незначне варварське підживлення у IV-VI століттях, представлене в основному сарматами. Пізніше у горнилі культурно-релігійного життя міста ця домішка асимілюється і до VII-X ст. місто знову стає винятково грецьким не лише з культурної, але й з антропологічної точки зору6.

На сучасному етапі ця схема викликає сумніви. 3 одного боку, через те, що багато візантійських міст, оточених, як і Херсон, варварами, до VII століття значно оновили свій етнічний склад ${ }^{7}$. Це, як відомо, вплинуло навіть на огрубіння грецької мови ${ }^{8} .3$ другого боку, письмові джерела так само суперечать висновкам дослідників про грецьке домінування у етнічному складі містян 9

Причин такого неспівпадання бачиться декілька. В першу чергу, це база джерел, спираючись на які були зроблені висновки про етнічний склад Херсонеса-Херсона. В основному йдеться про матеріали, отримані $з$ поховань. При цьому дослідники стикалися з низкою об'єктивних проблем - перемішуванням і зсуванням археологічних контекстів, низьким рівнем фіксації результатів розкопок XIX - початку XX ст, відсутністю планомірного кваліфікованого антропологічного аналізу виявлених людських кістяків. Другою проблемою в історіографії питання є розмитість критеріїв, маркерів присутності етносу в місті ${ }^{10}$.

Так, у дослідженнях А. Л. Якобсона, В. М. Зубаря, А. І. Айбабіна, С. Б. Сорочана домінуючим маркером є матеріали 3 поховань. На другому місці - предмети побуту, отримані, головним чином, з похоронних комплексів і розкопок некрополя. 3 тієї ж частотою критерієм виступає інформація, отримана з надгробних написів. Далі використовується, але вже значно рідше, аналіз техніки будівництва житлової архітектури, культові споруди. В останню чергу залучаються непрямі дані письмових джерел, що дають досить спірну інформацію і тому використовуються не часто ${ }^{11}$.

Найбільш інтенсивна дискусія про присутність варварського населення в етнічному складі міста розгорнулася навколо сарматів. 3'явившись за пізньоантичної доби, вони таємничо розчиняються у ранньовізантійскому міському середовищі або йдуть 3 міста. Їх присутність, в першу чергу, визначалася в історіографії за матеріалами поховальних комплексів ${ }^{12}$.

Найхарактернішою рисою сарматської приналежності померлих вважають штучну деформацію черепа. Як відзначають А. Л. Якобсон, В. М. Зубар і В. І. Кадєєв, поховання 3 деформованими черепами з'являються в некрополі Херсонеса не раніше II ст. н. е. ${ }^{13}$ У III-IV ст. н. е. їхня кількість значно збільшується, а деякі знахідки датують і початком V ст. Усього з 1889 р. по 1911 рр. розкопками було відкрито 33 поховання, більшість 3 яких датується кінцем IV ст. ${ }^{14}$ При цьому деякі з них мали риси християнського обряду, деякі були розграбовані, через що не піддаються релігійній ідентифікації ${ }^{15}$. Так, наприклад, у склепі № 620 було виявлено поясну пряжку з хрестом ${ }^{16}$. Таким чином, ми можемо припустити, що якась група варварського населення, швидше за все хрещеного, з'являється у місті в другій половині IV ст. і доживає тут до початку V ст. Потім «деформати» практично зникають; пізніші знахідки поодинокі, але також ідентифікуються як християнські.

Як відзначає С. Б. Сорочан, рідкісні власники деформованих черепів, поховані не пізніше VI-VII ст. в некрополі біля куртини 1 західної оборонної стіни і поряд із Карантинною бухтою, виявлені в типових пізньоримских склепах з нішами-лежанками або у вирубаних гробницях. Останні продовжували використовуватися для поховання християн, і поховані цілком могли бути християнами, судячи зі знахідки в інвентарі великої срібної пряжки з хрестом на прямокутному щитку, бронзової пряжки зі щитком у формі хреста, світильника-свічника у вигляді трубки на мисці і вапнякового надгробку у вигляді хреста. Ці так звані «макрокефали» з високим варіантом циркулярної або лобно-потиличної деформації, можливо, походили з числа привілейованих аланів або сараматів ${ }^{17}$. На території поруч з усипальницею св. Василя у склепі без номера було знайдено три кістяки «макрокефалів» 3 «уламками грубих глиняних горщиків» і 14-гранні підвіски до сережок, характерні для прикрас варварів V-VI ст. ${ }^{18}$ Цим обмежуються всі відомі на сьогодні знахідки «деформатів» для раннього середньовіччя.

Кримський антрополог О. В. Іванов на загал підтверджує спостереження істориків щодо сарматського компонента в етнічному складі Херсона ранньовізантійського часу, відзначаючи, що за всю історію дослідження некрополя міста описано 44 поховання, що 
містять не менш 94 кістяків зі штучною деформацією черепа. Це більше, ніж на Боспорі, але не більше $2 \%$ від загальної кількості поховальних комплексів ${ }^{19}$. Дослідник відзначає абсурдність плутанини в ідентифікації етносу, що трапляється серед істориків, які називають володарів деформованих черепів чи то сарматами, чи то аланами, оскільки сарматські серії з різних географічних регіонів при деякій варіабельності окремих ознак становлять єдиний антропологічний тип ${ }^{20}$.

Хронологічно О. В. Іванов також розподіляє час поховання «деформатів» за тими ж групами, що й історики - III-V ст. (більшість) і VI-VII ст. як поодинокі ${ }^{21}$. Таким чином, наявність сарматського компонента в етнічному складі ранньосередньовічного Херсонеса не викликає сумніву, але залишається незрозумілим, чим можна пояснити збільшення його кількості в кінці IV ст. і практично зникнення в подальшому. Традиційно відповідь на це питання звучить так: сармати начебто були в окрузі Херсонеса і потрапили в місто, а пізніше їхні нащадки ромеїзувалися під впливом панівної грецької культури ${ }^{22}$. Але якщо припустити, що значна частина 3 похованих цього періоду були хрещеними, в даному контексті привертає увагу житійний сюжет, пов'язаний з переселенням у місто християн єпископом Еферієм наприкінці IV ст. ${ }^{23}$ Їхня кількість сягала близько п'ятисот осіб ${ }^{24}$. На думку А. Ю. Виноградова, не здається неймовірною й можливість ініційованого імператором переселення до Херсонеса якихось, наприклад, малоазійських християн. Але якщо припустити, що країною ромеїв могли вважати і округу Херсонеса, то цілком ймовірно, під «іменитими християнами з сім'ями» укладач житій, місцевий мешканець, мав на увазі представників хрещеної сарматської знаті, яких наприкінці IV ст. переселили до міста, де вони і були згодом поховані ${ }^{25}$.

Піддає сумніву зникнення варварського компоненту в етнічній мозаїці ранньосередньовічного Херсонеса-Херсона до Х ст. і антрополог О. В. Іванов. Антропологічні матеріали некрополів міста привертали увагу дослідників вже у XIX ст. ${ }^{26} \mathrm{O}$. В. Іванов детально розглянув історіографію питання, проаналізувавши найбільш репрезентативні вибірки ранньосередньовічних черепів з розкопаних у різний час некрополів Херсонеса ${ }^{27}$. Аналізуючи матеріали з розкопок Г. Б. Бєлова, В. М. Зубаря, матеріал, зібраний К. Ф. Соколовою з розкопок Р. Х. Лепера 1912 р. і з розкопок О. І. Домбровського, він дійшов висновку, що більшість досліджених серій, в основному, відбили антропологічну ситуацію, репрезентативну, швидше, для періоду IV-VI ст. і, можливо, VII ст.; серії були мезо- і доліхокранними. Вони представляють традиційний європеоїдний тип грецького населення, походження якого досі залишається спірним. Як слушно зазначив В. М. Зубар, для цього періоду «поховальні комплекси з варварськими рисами буквально тонуть в масі могил, грецька етнічна приналежність яких не викликає сумніву» ${ }^{28}$.

Разом з тим, вже в пізньоантичному Херсонесі, як було зазначено вище, окремо виділяють групу з сарматськими антропологічними рисами, якій притаманна мезо-бракіхранія ${ }^{29}$. Проте виділити цю етнічну групу антропологічно для ранньовізантійського часу складно через відсутність матеріалу VIII-IX ст. Це робить необхідним звернення до матеріалів пізнішого часу, досліджених значно краще ${ }^{30}$. У різний час до наукового обігу було введено вісім херсонеських антропологічних серій X-XIV ст. ${ }^{31}$ Узагальнивши їх, О. В. Іванов дійшов висновку, що до X ст. антропологічний склад Херсона все ж значно змінився: на зміну традиційному грецькому мезо- і доліхокранному населенню приходить брахікранний тип, характерний для сарматів та інших варварських народів, що оточували місто. При цьому зберігається значна кількість черепів грецького антропологічного типу. Однак вони вже не становлять переважної більшості, як це було раніше. Виходячи з цього, можна вважати, що 3 антропологічної точки зору до X ст. відбулася певна варваризація зовнішнього вигляду міського населення, яка не відбилася на матеріальній культурі, що залишалася традиційно ромейскою. Зрозуміло, така зміна антропологічних типів не могла відбутися за короткий період, навіть за одне століття, оскільки це призвело б до помітних змін в міській культурі. Сам О. В. Іванов, хоча і обережно, зауважує, що «носії деяких антропологічних комплексів, що фіксуються для X-XIV ст., 3'являються в складі населення міста значно раніше» ${ }^{32}$.

Більш того, носії брахікранного типу у значній кількості з'являються в Криму з другої половини VIII ст. ${ }^{33}$ Тоді ж вони, на наш погляд, почали невеликими групами потрапляти в Херсон, посилюючи антропологічну варваризацію міста, розпочату свого часу сарматами. Невеликі групи християнізувались, романізувались, й у побуті нічим не відрізнялися від 
корінного населення міста, втім, розмиваючи і змінюючи його панівний антропологічний склад. Так поступово відбувалася зміна зовнішнього вигляду мешканців Херсона. Подібна інтерпретація етнічних процесів дозволяє краще зрозуміти, чому письмові джерела, авторами яких були вихідці з метрополії, дають настільки упереджену оцінку жителям міста, починаючи вже з VII ст.

Потрапивши в орбіту імперської зовнішньої політики, Херсонес-Херсон завжди сприймався як окраїна Візантії, небезпечна для життя, оточена дикими варварами. Прокопій Кесарійський ${ }^{34}$ у всіх ранніх історичних творах, де згадується Херсон, немов би підкреслює, визначає особливе становище міста в імперській геополітиці і складність його оточення: «А від Херсона, найвіддаленішого міста римської землі ...». У перекладі Х.-Ф. Байєра це звучить ще більш наочно: «... від міста Херсона, який є останнім у землі римлян» ${ }^{35}$. У «Війні з готами» (553р.) Прокопій уточнює: «Якщо йти 3 міста Боспора в місто Херсон, що лежить у приморській області і з давніх пір теж підпорядковане римлянам, то всю область між ними займають варвари з племен гунів. ... Від міста Херсона до гирла річки Істра, яку називають також Дунаєм, шляху днів десять, всі ці місця займають варвари» ${ }^{36}$. Те ж він відзначає і в пізнішому трактаті «Про споруди» ${ }^{37}$.

При цьому, зважаючи на варварське оточення міста, Прокопій ще не переносить цю характеристику на самих жителів. Однак вже 655 року папа римський Мартин I у своїх листах $€$ доволі радикальним в оцінці справжнього складу міського населення: «Адже ті, хто мешкає в цій області, всі є язичниками, і язичницькі звичаї сприйняли ті...» ${ }^{38}$, хто відомий, як місцеві. Можна скільки завгодно вважати, що він «мав на увазі не те, що сказав» $\mathrm{i}$ продовжувати дискутувати, але все ж незаперечний факт полягає в тому, що міські жителі в очах столичного гостя були, м'яко кажучи, «незвичайними». Виходячи 3 цього, можна вважати, що вже за часів перебування Мартина в місті стали помітні антропологічні зміни, притаманні, принаймні, частині населення.

Криваві події, пов’язані з помстою Юстиніана II херсонітам за відмову підтримати його проти василевса, могли призвести до необхідності поповнити міський склад жителями округи. Так, Феофан Сповідник повідомляє, що «ромеї, прибувши в Херсон, захопили фортецю, бо ніхто їм не став неслухняним, і знищили всіх мечем, крім підлітків, пощадивши їх як недбайливих і придатних в служіння» ${ }^{39}$. Безумовно, повідомлення хроніста $\epsilon$ істотним перебільшенням, оскільки далі в тому ж тексті він говорить про опір городян повторній експедиції ${ }^{40}$, проте, у будь-якому випадку, слід визнати, що у VIII ст. місто зазнало істотних демографічних втрат, які могли посилитися коштом пандемії чуми середини століття.

Наслідки таких змін, на наш погляд, відбилися в оцінці етнічного складу міського населення, даної укладачами версії набуття мощей св. Климента Константином Філософом, викладеної Анастасієм бібліотекарем. Автор всюди зазначає, що Константин спілкувався саме 3 херсонеситами. Згідно з цим виходить, що склад міського населення на час перебування імперського емісара в місті повністю змінився. «Але всі жителі того місця будучи не тубільцями, а прибульцями з різних варварських народів, навіть люті розбійники, запевняли, що нічого не знають про те, що він ... каже» ${ }^{41}$.

Аналогічне повідомлення дає ще одна версія перенесення мощей св. Климента: «Всі оголосили, що, як прибульці з різних народів, а не місцеві уродженці, нічого не знають, про що запитує (...)» $\rangle^{42}$. Таким чином, до середини IX ст. міське населення, ймовірно, істотно варваризовувалося, несучи варварські антропологічні риси, однак увібравши ромейську культуру, мову, віру.

Чи було оновлення міського населення в ранньосередньовічний час - 3 VII ст. i, особливо, 3 другої половини VIII ст. - унікальної ситуацією для провінційного Херсонеса? ${ }^{43}$. У жодному разі. Головним каталізуючим фактором, який пришвидшив міграційні процеси, що призвели до зміни етнічного складу візантійський міських центрів цього періоду, стали перманентні спалахи так званої Юстиніанової чуми (541-750рр.). Вони, за зауваженням Діонісія Статакопулоса, склали «вододіл у демографічному розвитку візантійської держави» ${ }^{44}$. Інфекція поширювалася за допомогою морських комунікацій; Херсонес-Херсон як торговий портовий центр не міг опинитися за орбітою загальноімперської катастрофи. Великі міста втрачали до двадцяти відсотків населення ${ }^{45}$. Так, остання хвиля чуми 745 749 рр. в черговий раз поставила імперію на межу спустошення ${ }^{46}$; Константинополь було потрібно заселяти цілими сім'ями з Греції і Егейських островів, а також ремісниками, які 
прибули до столиці на відновлювальні роботи ${ }^{47}$. Швидше за все, подібна практика і привела до оновлення антропологічного складу провінційного архонтного, а потім і фемного міста, яке систематично вбирало до свого складу після пандемії або військової катастрофи до $20 \%$ населення відповідно до періодичності хвиль чуми - раз на 12-20 років впродовж VIIVIII ст., причому почалися ці процеси ще раніше, в епоху Великого переселення народів.

В цілому, зіставлення даних антропології, археології і письмових джерел дозволяе скласти таку етнічну мозаїку. Вже період Великого переселення народів долучив нові компоненти до етнічного складу Херсонеса, в якому мешканці міста, скріплені новою вірою, загальною ромейской культурою і мовою, змогли згуртуватися у новий поліетнічний моноліт, зрозумілий для себе, але все ж чужий і незвичний для столичних інтелектуалів. Вони, з одного боку, були типовими візантійцями, які визнавали лише кофесійну самоідентифікацію, але, з другого боку, варварське вливання, навіть якщо воно не виявилося на матеріальному рівні, не могло не відібитися на антропологічному вигляді міських мешканців, а значить, вплинуло на повсякденну культуру поведінки, невловиму в археологічних джерелах, але доволі відчутну за нотатками тих, хто стикався з цими мешканцями особисто.

${ }^{1}$ Древняя синагога в Херсонесе Таврическом: Материалы и исследования Причерноморского Проекта 1994-1998 гг. Т. 1. / Золотарев М. И., Коробков Д. Ю, Ушаков С. В., Макленнан Р., Оверман А., Оливье Дж., Эдвардс Д., Линстром Г., при участии Е. Олениной. М., Севастополь, 2013. С. 256.

${ }^{2}$ Романчук А. И. Исследования Херсонеса-Херсона. Раскопки. Гипотезы. Проблемы. Т. 2. Тюмень, 2008. С. 153.

${ }^{3}$ Древняя синагога в Херсонесе Таврическом... С. 256.

${ }^{4}$ Сорочан С. Б. Византийский Херсон. Очерки истории и культуры. Харьков, 2005. Ч. I. С. 214 216; Якобсон А. Л. Раннесредневековый Херсонес // Материалы и исследования по археологии СССР (далее - МИА)). № 63. М., Л., 1959. С. 256-259; Зубарь В. М. Этнический состав населения Херсонеса Таврического первых веков нашей эры (по материалам некрополя) // Материалы к этической истории Крыма VII в. до н. э. - VII в. н. э. К., 1987. С. 78-101; Айбабин А. И. Этническая история ранневизантийского Крыма. Симферополь, 1999. С. 49.

${ }^{5}$ Айбабин А. И. Этническая история ранневизантийского Крыма... С. 49.

${ }^{6}$ Сорочан С. Б. Византийский Херсон ... С. 214-216; Якобсон А. Л. Раннесредневековый Херсонес ... С. 256-259; Зубарь В. М. Этнический состав ... С. 78-101; Айбабин А. И. Этническая история ... C. 49 .

7 Липшиц Е. Э. Очерки истории византийского общества и культуры: VIII - первая половина IX в. М., Л., 1961. С. 34-35.

${ }^{8}$ Поляковская М. А., Чекалова А. А. Византия: быт и нравы. Свердловск, 1989. С. 115.

${ }^{9}$ Письма Папы Мартина // Сорочан С. Б. Византийский Херсон... С. 1295-1296; Феофан Исповедник. Хронография // Сорочан, С. Б. Византийский Херсон... С. 1325; Письмо Анастасия библиотекаря епископу Гаудериху // Сорочан С. Б. Византийский Херсон... С. 1453; Житие с перенесением мощей св. Климента // Сорочан С. Б. Византийский Херсон... С. 1447

${ }^{10}$ Сорочан С. Б. Византийский Херсон ... С. 214-216; Якобсон А. Л. Раннесредневековый Херсонес ... С. 256-259; Зубарь В. М. Этнический состав ... С. 78-101; Айбабин А. И. Этническая история ... C. 49.

${ }^{11}$ Сорочан С. Б. Византийский Херсон ... С. 214-216; Якобсон А. Л. Раннесредневековый Херсонес ... С. 256-259; Зубарь В. М. Этнический состав ... С. 78-101; Айбабин А. И. Этническая история ... C. 49 .

12 Зубарь B. М. Этнический состав населения Херсонеса Таврического первых веков нашей эры (по материалам некрополя). Материалы к этической истории Крыма VII в. до н. э. - VII в. H. э. К., 1987. С. 78-101; Кадеев В. И. Херсонес Таврический в первые века нашей эры. Харьков, 1981. C. 144 .

13 Зубарь В. М. Этнический состав ... С. 85; Кадеев В. И. Херсонес Таврический... С. 85; Якобсон А. Л. Раннесредневековый Херсонес ...С. 256.

14 Якобсон А. Л. Раннесредневековый Херсонес ... С. 256.

15 Производство археологических раскопок в Херсонесе // Отчет Археологической комиссии за 1896. - Архив Института истории материальной культуры Академии наук СССР. Ф. АК. Д. № 4/1896. Л. 176

${ }^{16}$ Производство археологических раскопок в Херсонесе ... Л. 176.

${ }^{17}$ Сорочан С. Б. Византийский Херсон. С. 214-216; Белов Г. Д. Западная оборонительная стена и некрополь возле нее (раскопки 1948 г.) // МИА. № 34. М., Л., 1953. С. 245-254; 3убарь B. M., Pblжев С. Г. Отчет о раскопках Херсонесского некрополя в 1975 г. // Архив Национального заповедника Херсонес Таврический (далее - НЗХТ). Д. 1778. Л. 15, 17; Отчет за 1905 год // Архив НЗХТ. Д. 14. 
Л. 33; Косиюшко-Валюженич К. К. Отчет о раскопках в Херсонесе Таврическом в 1905 году // Известия археологической комиссии. 1907. Вып. 25. С. 96.

${ }_{18}$ Якобсон А. Л. Раннесредневековый Херсонес ... С. 215.

${ }^{19}$ Иванов А. В. Население византийского Херсонеса по данным антропологии // Сорочан С. Б. Византийский Херсон. Очерки истории и культуры. Харьков, 2005. Ч. 2. С. 1633.

${ }^{20}$ Фринштейн Б. В. Сарматы Нижнего Поволжья в антропологическом освещении // Антропологические данные к вопросу великом переселении народов. Авары и сарматы. Л., 1970. С. 116-117.

${ }^{21}$ Иванов А. В. Население византийского Херсонеса... С. 1633-1634.

${ }^{22}$ Сорочан С. Б. Византийский Херсон ... С. 216-217.

${ }^{23}$ Жития св. Епископов Херсонских в грузинской минее // Могаричев Ю. М., Сазанов А. В., Саргсян Т. Э., Сорочан С. Б., Шапошников А. К. Жития епископов Херсонских в контексте истории Херсонеса Таврического - Нартекс - Byzantina Ukrainensis. Харьков, 2012. Т. 1. С. 93.

${ }^{24}$ Армянские тексты // Могаричев Ю. М., Сазанов А. В., Саргсян Т. Э., Сорочан С. Б., Шапошников А. К. Жития епископов Херсонских в контексте истории Херсонеса Таврического - Нартекс - Byzantina Ukrainensis. Харьков, 2012. T. 1. С. 119.

${ }^{25}$ Виноградов А. Ю. «Миновала уже зима языческого безумия...». Церковь и церкви Херсона в IV веке по данням литературных источников и эпиграфики. М., 2010. С. 56

${ }^{26}$ Богданова A. В. О черепах из Крымских могил, могил Херсонеса и Инкермана // Известия общества любителей антропологии и этнографии. Антропологическая выставка. 1884. Вып. 1. Ч. 1. C. 56.

${ }^{27}$ Иванов А. В. Палеоантропология Крыма. Первоисследователи // Сугдея, Сурож, Солдайя в истории и культуре Руси - Украины. Материалы международной научной конференции. К., Судак, 2002. C. $114-115$.

${ }_{28}^{28}$ Зубарь В. М. Этнический состав ... С. 98.

${ }^{29}$ Иванов А. В. Население византийского Херсонеса ... С. 1632.

${ }^{30}$ Иванов А. В. Этнические процессы в ЮЗ Таврике Х-ХІІІ вв. и антропологические характеристики населения городских центров региона // Вестник антропологии. М., 2004. С. 108-113; Иванов A. B. Антропологический материал из некрополя на Северном берегу Херсонеса Таврического // Вестник антропологии. 2007. Вып. 15. Ч. 2. С. 300-309.

31 Дебеи Г. Ф. Антропологический состав населения средневековых городов Крыма // Сборник музея антропологии и этнографии. М., Л., 1949. Т. 12. С. 334-385; Зиневич Г. П. Антропологические материалы средневековых могильников Юго-Западного Крыма. К. 1973. С. 140-246; Назарова T. А. Краниологический материал из склепов с некрополя Херсонеса // Антропологические материалы из склепов некрополя Херсонеса // Антропологические мптериалы из могильников Юго-Западного Крыма. К., 1990. С. 26-31; Иванов А. В. Антропологические материалы из раскопок часовни в квартале Х «б» Херсонеса 1996 г. // Херсонесский сборник. С. 253-265.

${ }^{32}$ Иванов А. В. Население византийского Херсонеса ... С. 1636-1637.

${ }^{33}$ Там же. С. 1636-1637. 1239.

${ }^{34}$ Прокопий Кесарийский. Война с персами // Сорочан С. Б. Византийский Херсон... С. 1238

${ }^{35}$ Байер $X$. . История крымских готов как интерпритация Сказания Матфея о городе Феодоро. Екатеринбург, 2001. С. 33 1241.

${ }^{36}$ Прокопий Кесарийский. Война с готами // Сорочан С. Б. Византийский Херсон ... С. 1240-

${ }^{37}$ Прокопий Кесарийский. О постройках // Сорочан С. Б. Византийский Херсон ... С. 1243.

${ }^{38}$ Письма Папы Мартина // Сорочан С. Б. Византийский Херсон ... С. 1295-1296.

39 Феофан Исповедник. Хронография // Сорочан С. Б. Византийский Херсон ... С. 1325.

${ }^{40}$ Там же. С. 1326.

${ }^{41}$ Письмо Анастасия библиотекаря епископу Гаудериху // Сорочан С. Б. Византийский Херсон ... C. 1453

42 Житие с перенесением мощей св. Климента // Сорочан С. Б. Византийский Херсон ... С. 1445 1447.

${ }^{43}$ Статакополус Д. Население, демография, заболевания // Оксфордское руководство по византинистике Ред. Э. Джеффрис, Дж. Хэлдон, Р. Кормак; пер. с англ. В. В. Швец; гл. ред. С. Б. Сорочан; ред. А. Н. Домановский, П. Е. Михалицын, А. Г. Чекаль. Вып. 1. Харьков: Майдан, 2014. - Нартекс - Byzantina Ukrainensia. T. 3. C. 316.

${ }^{44}$ Stathakopoulos D. Famine and Pestilence in the Late Roman and Early Byzantine Empire. A Systematic Survey of Subsistence Crises and Epidemics. Ashgate, 2004. P. 111; Little L. K. Plague and the End of Antiquity. Cambridge, 2007. P. 55.

${ }^{45}$ Статакополус Д. Население, демография, заболевания... С. 316.

${ }^{46}$ Little L. K. Plague and the End of Antiquity. Cambridge, 2007. P. 55.

${ }^{47}$ Статакополус Д. Население, демография, заболевания... С. 317. 